\title{
Organic Fertilizer for Production of Toona ciliata Seedlings
}

\author{
Rudinei De Marco ${ }^{1}$ (D), Edison Rogerio Perrando ${ }^{1}$ (D), Bruno Conte ${ }^{1}$ (D), \\ Luis Paulo Baldissera Schorr ${ }^{1}$
}

${ }^{1}$ Universidade Federal de Santa Maria - UFSM, Westphalen/RS, Brasil

\begin{abstract}
This study evaluated the effect of different sources of organic fertilizer and their most appropriate proportions to produce Toona ciliata seedlings. Broiler litter and cattle manure were used as organic fertilizer at four proportions in the substrate $(0,15,30$, and $45 \%)$. A control treatment was adopted with $6 \mathrm{~kg}$ controlled-release fertilizers ( $\mathrm{m}-3$ substrate). The following parameters were assessed: germination, seedling height, stem diameter, and shoot and root dry matter, as well as the Dickson Quality Index. Cattle manure did not provide satisfactory results, whereas the use of broiler litter in the substrate resulted in seedling development similar to that of the control treatment. In conclusion, concentrations up to $30 \%$ of broiler litter can be recommended to substrate composition, and greater proportions of this compound $(>30 \%)$ preclude seed germination.
\end{abstract}

Keywords: Australian cedar, broiler litter, cattle manure. 


\section{INTRODUCTION}

Introduction of exotic tree species in Brazil assisted with conducting the socio-economic development of the Country, especially because of their high levels of productivity. In addition to attending the demand for forest products and bringing economic returns, these plants can prevent the irrational deforestation of native forests (Sampaio et al., 2000; Thomas, 2007).

Australian cedar (Toona ciliata M. Roem. var. australis) is an exotic tree species belonging to the Meliaceae family that has been cultivated in Brazil for almost three decades (Ferreira et al., 2012). This species has great botanical similarity with cedar and mahogany - two Brazilian native species (Pinheiro et al., 2006). However, the Australian cedar has advantages over these Brazilian species, such as short production cycle and absence of attacks by Hypsipyla grandella - a pest that attacks the apical bud of the Meliaceae family (Ferreira et al., 2012).

A predicting factor of forest productivity and quality is the utilization of high-quality seedlings (Wendling et al., 2006). Therefore, to produce high-quality seedlings it is necessary to choose a suitable substrate, as well as adequate nutrient source and amount of fertilizer, because most of the substrates used for seedling production are poor in nutrients considered essential to plant growth (Assenheimer, 2009), and because the substrates influence the germination and growth of seedlings of forest species (Da Ros et al., 2015).

Among the stimulants used in seedling production, mineral controlled-release fertilizers (encapsulated, named CFR) containing water-soluble compounds (NPK and some micronutrients) are highlighted. These fertilizers are capsules involved by a semipermeable membrane that expands and contracts according to ambient temperature and humidity conditions, causing gradual and osmotic release of nutrients into the substrate (Bennett, 1996). However, CFR use leads to a relatively expensive manufacturing process, which reflects on the final production cost of forest seedlings (Rossa et al., 2011).

Alternative nutrient sources, such as organic fertilizers, are used in seedling production (Giracca \& Nunes, 2012). The organic materials most commonly used to compose substrates for forest seedling production are cattle manure, biosolids, broiler litter, and rice husk ash (Rondon \& Ramos, 2010).

The choice of a suitable organic material and its incorporation percentage into the substrate are important factors for the formation and patterning of seedlings (Carvalho et al., 2004). Santos et al. (2010) reported that the use of organic materials, especially from waste, has constituted a viable alternative in terms of environmental preservation. This has significantly decreased the application of chemical fertilizers and minimized environmental contamination. In addition, organic materials can be easily acquired in rural properties.

Research addressing different sources and proportions of organic fertilizers in the production of Toona ciliata seedlings is still incipient, and further specific studies are required. In this context, this study aimed to evaluate the effect of different sources of organic fertilizers and their most appropriate proportion in the substrate for the development of Toona ciliata seedlings.

\section{MATERIALS AND METHODS}

This study was conducted in a greenhouse of the Federal University of Santa Maria (UFSM), Campus Frederico Westphalen, located in the northern Rio Grande do Sul state, Brazil. This region is 465 masl on average, at latitude $27^{\circ} 23^{\prime} 47^{\prime \prime} \mathrm{S}$ and longitude $53^{\circ} 25^{\prime} 41^{\prime \prime} \mathrm{W}$.

Toona ciliata seeds were acquired from the Forestry Laboratory of the Forest Investigation Society (SIF) located in Viçosa, Minas Gerais state. First, the batch was submitted to prior analysis to eliminate any impurities. Sowing was performed in polypropylene containers (tubes) with $175 \mathrm{~cm}^{3}$ capacity, using two seeds per tube. When the seedlings presented the first pair of true leaves, they were subjected to thinning to establish only one seedling per tube. For this thinning, the aspect of plant health and vigor was considered.

The experiment was conducted under complete randomized design in a $2 \times 4$ factorial arrangement, with two sources of organic fertilizer (broiler litter and cattle manure) and four proportions of these fertilizers to the substrate $(0,15,30$, and $45 \%)$. A control treatment containing a dosage of $6 \mathrm{~kg}$ per cubic meter of controlled-release fertilizer (CFR) was also used, following the general recommendation for some 
forest species (Moraes et al., 2003; Rossa et al., 2013). Each treatment consisted of 90 seedlings divided into five replicates. Volume-by-volume (v:v) was used to formulate the proportions.

As part of the finalization of the tanning process, the organic fertilizers remained at rest for 30 days prior to incorporation into their correct proportions to the standard substrate for growing plants. Composition was $70 \%$ commercial substrate Tecnomax and 30\% sifted soil. Broiler litter was composed of 12 batches of chickens in confinement, i.e., the broiler litter used to develop 12 batches of chickens $(\mathrm{N}=5.8 \% ; \mathrm{P}=14.08 \%$; $\mathrm{K}=20.16 \%$ ), whereas cattle manure was collected from animals raised under extensive grazing that did not receive concentrated food supplements $(\mathrm{N}=0.81 \%$; $\mathrm{P}=0.92 \% ; \mathrm{K}=0.37 \%$ )

The controlled-release fertilizers used as control treatment (CFR) had the following chemical composition: $\mathrm{C}=13 \%, \mathrm{P}_{2} \mathrm{O}_{5}=6 \%, \mathrm{~K}_{2} \mathrm{O}=16 \%, \mathrm{Ca}=3.5 \%, \mathrm{~S}=2.3 \%$, and $\mathrm{Mg}=1 \%$ for macronutrients, and $\mathrm{Fe}=0.45 \%, \mathrm{Mn}=1.4 \%$, $\mathrm{Cu}=0.05 \%, \mathrm{Zn}=0.05 \%$, and $\mathrm{Mo}=0.02 \%$ for micronutrients.

The following variables were assessed 180 days after sowing: seedling height $(\mathrm{H})$, stem diameter (SD), shoot dry matter (DMS), and root dry matter (DMR). Seedling height was measured using a graduated ruler $(30 \mathrm{~cm})$ as the distance from the stem to the last leaf axil. $\mathrm{SD}$ was measured using a digital caliper. For evaluation of DMS and DMR, plant materials from the shoots and roots were separated for subsequent drying in air circulation oven $\left(65^{\circ} \mathrm{C} \pm 1^{\circ} \mathrm{C}\right)$ until $g$ constant weight was reached. The dry biomass was weighed on an analytical balance. Based on the evaluation of the morphological variables, the Dickson Quality Index (Dickson et al., 1960) was calculated by the formula $\mathrm{DQI}=[\mathrm{DMS}+\mathrm{DMR} /(\mathrm{H} / \mathrm{SD}+\mathrm{DMS} / \mathrm{DMR})]$.

Results were submitted to analysis of variance (ANOVA) with the average of treatments analyzed by regression and/or the Dunnett's test at 5\% probability of error.

\section{RESULTS AND DISCUSSION}

The ANOVA showed significant interaction $(p \leq 0.05)$ between the organic fertilizer factor and the fertilizer proportions for all variables of $T$. ciliata seedlings. The height of $T$. ciliata seedlings was linearly increased with increasing of cattle manure proportions, whereas an increase in a quadratic effect to proportions was observed for broiler litter (Figure 1A). At 180 days, the broiler litter components generated a maximum height of $14.9 \mathrm{~cm}$ at the proportion of $45 \%$, whereas the same proportion of cattle manure resulted in plant height of $7.3 \mathrm{~cm}$. According to Pereira et al. (2010), this difference, in addition to being related to the nutrient content of these two fertilizers, can be associated with with their effect on the substrate regarding microbiological processes, aeration, structure, water retention capacity, and ambient temperature control.

Stem diameter was linearly increased with the increase of manure proportions. However, when utilizing broiler litter, stem diameter increased in smaller proportions, reaching a maximum point with $27 \%$ fertilizer, with further reduction at the highest proportion (Figure 1B). Pereira et al. (2010), studying substrate composition to produce seedlings of tamarind (Tamarindus indica), found the maximum growth of stem diameter at $46.1 \%$ broiler litter in relation to the control substrate. Costa et al. (2011) also observed a linear growth of stem diameter with increasing proportions of cattle manure in four arrays of Corymbia citriodora. This demonstrates the higher efficiency of broiler litter to provide greater diameter growth of seedlings compared with cattle manure.

The proportions of cattle manure did not significantly influence the production of root biomass (DMR). In contrast, broiler litter promoted an increase in this variable, reaching the maximum point $\left(6.08 \mathrm{~g} \mathrm{plant}^{-1}\right)$ at the estimated proportion of $37 \%$ (Figure 1C). Similarly to DMR, shoot dry matter (DMS) was not affected when cattle manure used; however, there was a linear increase with increasing proportions of broiler litter (Figure 1D). According to Silva \& Morais (2013), cattle manure as a substrate component also was not efficient for the production of seedlings of "olho-de-cabra" (Ormosia arborea).

In consonance with Frade et al. (2011), when studying the production of Ingazeiro (Inga edulis) seedlings, the proportion of $20 \%$ broiler litter $(+60 \%$ charcoal powder $+10 \%$ clay $+10 \%$ sand $)$ showed the highest values of DMS and DMR. This difference observed between studies for broiler litter percentages may be associated with the nutritional requirements of each species, as well as with the stabilization level and concentration of nutrients available to the plants. 
- Broiler litter

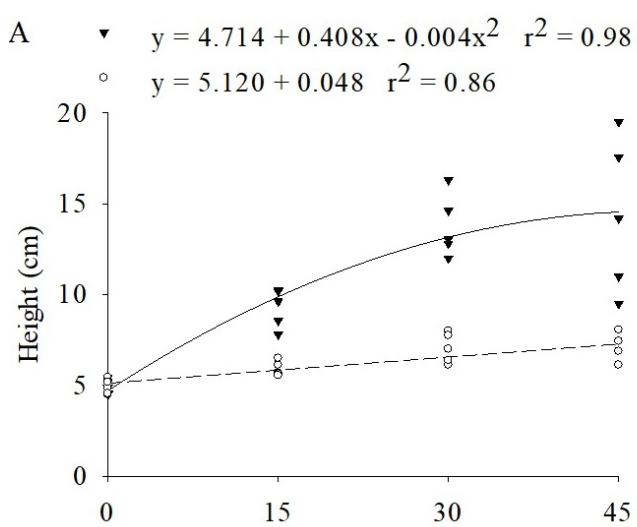

Proportions of organic fertilizers (\%)
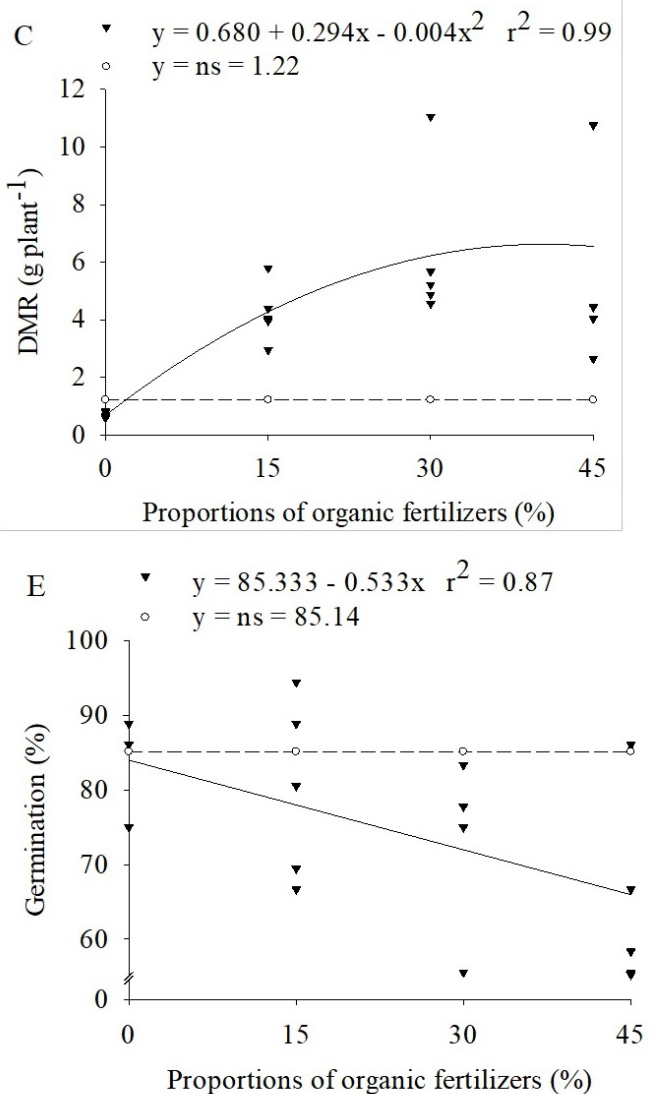

- Cattle manure

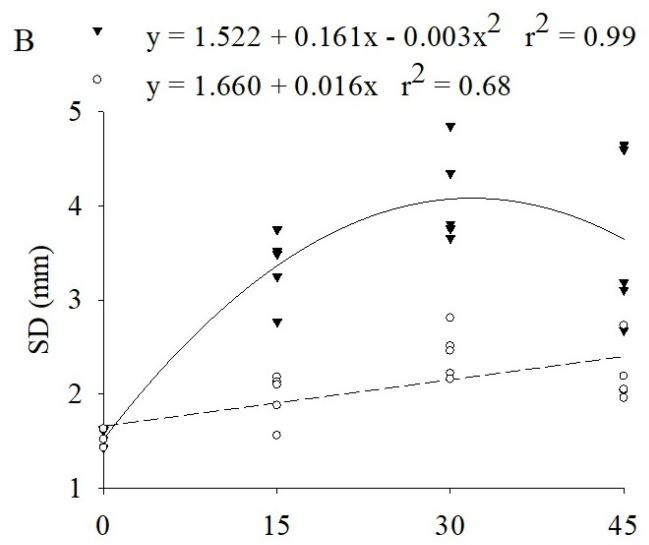

Proportions of organic fertilizers (\%)
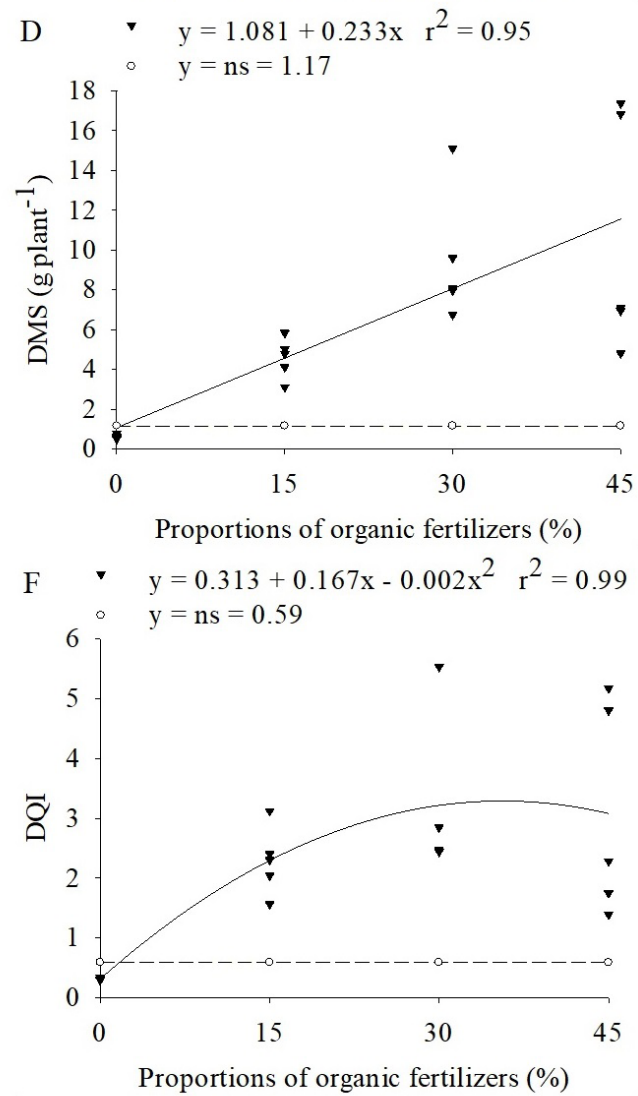

Figure 1. Regression equations for height (A), stem diameter - SD (B); root dry matter - DMR (C), shoot dry matter - DMS (D), germination (E), and Dickson Quality Index - DQI (F) in Toona ciliata seedlings in different proportions of broiler litter and cattle manure in the soil.

The proportions of cattle manure did not influence the germination of $T$. ciliata seeds, reaching an average germination of $85.1 \%$. Regarding broiler litter, an indirect relationship was observed, with increased broiler litter proportion resulting in a linear decrease in the germination capacity of seeds. At the proportion $45 \%$ broiler litter, the estimated germination was equal to $61.3 \%$, that is, $24 \%$ smaller than that of the control 
treatment (Figure 1E). Torres et al. (2011), in a study conducted with Jatropha (Jatropha curcas) seedlings, also found reduced germination using proportions $>10 \%$ broiler litter. Possibly, the reduction in germination is associated with the stability level of broiler litter. According to the Brazilian Society of Soil Science (SBCS, 2004), manure from animals fed with concentrate diets releases large amounts of chemicals. In addition, Gianello \& Ernani (1983) stated that the damage caused to plants due to the use of high proportions of organic material can be associated with the presence of toxic amounts of ammonia, nitrite, and salts.

The proportions of cattle manure did not affect the Dickson Quality Index (DQI). However, for broiler litter, a positive quadratic response occurred with increased proportions. As reported by Fonseca (2000), the DQI is identified as a good indicator of seedling quality, because its calculation considers the strength, balance and distribution of biomass. According to Gomes (2001), a high DQI value indicates better seedling quality. In this way, the point of maximum technical efficiency for the DQI was reached at the proportion of $42 \%$ broiler litter, resulting in a 3.79 value.

For height, stem diameter, root dry matter, and DQI, the proportions of cattle manure were statistically lower than those of the control treatment. As for shoot dry matter, the proportions of 30 and $45 \%$ did not differ from those of the control treatment. With respect to germination, no statistical differences in the comparison with the control treatment were observed for all proportions of cattle manure (Table 1). Jabur \& Martins (2002) reported that the choice of substrate is important, because it is the place where the root system will be developed, determining the growth of the shooting part of the seedlings. Therefore, care must be taken with the choice of the substrate and its proportions to produce seedlings. In this study, the proportions of cattle manure decreasingly influenced the growth of T. ciliata seedlings. Silva \& Morais (2013) also concluded that substrate containing cattle manure and soil (1:1) was inefficient to produce seedlings of "olho-de-cabra" (Ormosia arborea).

With the absence of broiler litter in the substrate, all the variables were statistically lower than those of the control treatment $\left(6 \mathrm{~kg} \mathrm{~m}^{-3}\right.$ controlled-release fertilizers) except for germination, which did not show statistical difference (Table 1). Using 15\% broiler litter in the substrate, no statistically significant difference was observed in seedling height in comparison with the control treatment. However, at the proportions of 30 and $45 \%$, there was an increase in plant height in relation to the control treatment.

Table 1. Statistical Summary and Dunnett's Test for height (H), stem diameter (SD), shoot (DMS) and root (DMR) dry matter, germination (GER), and Dickson Quality Index (DQI) of Toona ciliata seedlings produced with $6 \mathrm{~kg}$ controlled-release fertilizers - $6 \mathrm{M} \mathrm{m}^{-3}$ substrate (CRF - control) and different proportions of broiler litter and cattle manure.

\begin{tabular}{|c|c|c|c|c|c|c|c|}
\hline \multirow{2}{*}{\multicolumn{2}{|c|}{ Variables }} & $\mathbf{H}$ & SD & DMS & DMR & \multirow{2}{*}{$\begin{array}{c}\text { GER } \\
---\% \text {--- }\end{array}$} & \multirow{2}{*}{ DQI } \\
\hline & & $---\mathrm{cm}$--- & --- mm --- & \multicolumn{2}{|c|}{---- g plant ${ }^{-1}$---- } & & \\
\hline $\mathrm{F}$ & & 22.31 & 26.97 & 13.22 & 10.81 & 3.74 & 12.47 \\
\hline CV (\%) & & 19.73 & 15.59 & 30.76 & 24.45 & 13.2 & 21.13 \\
\hline Residual & & 2.89 & 0.18 & 5.68 & 2.88 & 14.21 & 0.64 \\
\hline LSD & & 2.99 & 0.74 & 4.2 & 2.99 & 6.64 & 1.4 \\
\hline CRF - control $\left(\mathrm{kg} \mathrm{m}^{-3}\right)$ & 6 & 10.44 & 3.60 & 5.32 & 5.47 & 80.20 & 2.79 \\
\hline \multirow{4}{*}{ Cattle manure (\%) } & 0 & $4.91 *$ & $1.53^{*}$ & $0.61 *$ & $0.70^{*}$ & $82.22 \mathrm{~ns}$ & $0.32 *$ \\
\hline & 15 & $5.90 *$ & $1.97^{*}$ & $0.84^{*}$ & $0.65^{*}$ & $85.56 \mathrm{~ns}$ & $0.34 *$ \\
\hline & 30 & $7.05 *$ & $2.43^{*}$ & $1.58 \mathrm{~ns}$ & $1.77^{\star}$ & $86.67 \mathrm{~ns}$ & $0.86^{*}$ \\
\hline & 45 & $6.93 *$ & $2.19^{*}$ & $1.66 \mathrm{~ns}$ & $1.75^{*}$ & $86.11 \mathrm{~ns}$ & $0.83 *$ \\
\hline \multirow{4}{*}{ Broiler litter (\%) } & 0 & $4.91^{*}$ & $1.53^{\star}$ & $0.61^{\star}$ & 0.70 * & $82.22 \mathrm{~ns}$ & 0.32 * \\
\hline & 15 & $9.29 \mathrm{~ns}$ & $3.36 \mathrm{~ns}$ & $4.58 \mathrm{~ns}$ & $4.22 \mathrm{~ns}$ & $80.00 \mathrm{~ns}$ & $2.29 \mathrm{~ns}$ \\
\hline & 30 & $13.76^{* *}$ & $4.09 \mathrm{~ns}$ & $9.50 \mathrm{~ns}$ & $6.28 \mathrm{~ns}$ & $73.33 \mathrm{~ns}$ & $3.23 \mathrm{~ns}$ \\
\hline & 45 & $14.35^{* *}$ & $3.65 \mathrm{~ns}$ & $10.61^{* *}$ & $6.53 \mathrm{~ns}$ & $57.78^{*}$ & $3.08 \mathrm{~ns}$ \\
\hline
\end{tabular}

${ }^{*}$ Significant difference and lower than the control (CRF - $6 \mathrm{~kg}$ controlled-release fertilizers $-\mathrm{m}^{-3}$ substrate); ${ }^{*}$ Significant difference and higher than the control (CRF - $6 \mathrm{~kg}$ controlled-release fertilizers - $\mathrm{m}^{-3}$ substrate); ${ }^{\mathrm{ns}}$ not significant according to the Dunnett's Test at $5 \%$ probability level; F - statistical F-test; CV (\%) - Coefficient of Variation; LSD - Least significant difference. 
For stem diameter, root dry mass, and the Dickson Quality Index, all broiler litter proportions did not differ from the control treatment. For shoot dry matter, no statistically significant differences were observed between the $15-30 \%$ proportions and the control treatment, but the proportion of $45 \%$ was statistically higher than the control for this variable (Table 1).

Results demonstrated the effective potential of adopting broiler litter in the composition of the substrate, thus favoring the early growth of seedlings similarly, or even more, than with the use mineral fertilization ( $6 \mathrm{~kg} \mathrm{~m}^{-3}$ controlled-release fertilizers). Pereira et al. (2010) also reported benefits in the utilization of broiler litter in substrate for seedling production. These authors concluded that $40 \%$ broiler litter and $60 \%$ soil can promote vigorous development in height, stem diameter, and dry biomass production in Tamarind (Tamarindus indica) seedlings. Most likely, this occurs because of the composition of nutrients; with adequate management, this organic fertilizer can partially or completely supply the necessary minerals (Luz et al., 2009).

Although a reduction in the average germination of $T$. ciliata seeds was observed, there was no statistical difference at the proportion of $30 \%$ broiler litter. Notwithstanding, the use of $45 \%$ broiler litter provided significant reduction in germination compared with that of the control treatment (Table 1). Miranda et al. (1998), studying the development of alternative substrates, found that broiler litter is an organic compound rich in ammonia, and that its utilization should not exceed $30 \%$ of the total mixture. These results demonstrate the importance of the organic material composition used as a nutrient source to produce T. ciliata seedlings, especially regarding the establishment of appropriate percentages of this material in substrate composition in order to avoid physiological damage to plants at early stage of development in greenhouse.

\section{CONCLUSION}

Results of this study show that cattle manure does not provide satisfactory increment to the growth of Toona ciliata seedlings. In contrast, broiler litter considerably favored the initial growth of seedlings, with regular similarity to the results obtained with mineral fertilizer (controlled-release fertilizers).
Based on this study, proportions of up to $30 \%$ broiler litter in the composition of the substrate are recommended, and greater proportions can reduce the germination percentage of Toona ciliata seeds.

\section{SUBMISSION STATUS}

Received: 9 may, 2016

Accepted: 15 mar., 2018

\section{CORRESPONDENCE TO}

\section{Rudinei De Marco}

Departamento de Ciências Agronômicas e Ambientais, Universidade Federal de Santa Maria - UFSM, Campus Frederico Westphalen, Linha 7 de Setembro, s/n, CEP 9840000, Frederico Westphalen, RS, Brasil e-mail: rudineidemarco@hotmail.com

\section{REFERENCES}

Assenheimer A. Benefícios do uso de biossólidos como substratos na produção de mudas de espécies florestais. Revista Ambiência 2009; 5(2): 321-330.

Bennett E. Slow-release fertilizers. Virginia Gardener Newsletter [online]. 1996 [cited 2015 Oct 1]; 11(4). Available from: www.ext.vt.edu/departments/envirohort/ articles/misc/slowrels.html

Carvalho JEU, Furlan J Jr, Müller CH, Teixeira LB, Dutra S. Efeito de doses percentuais de cama de frango na produção de mudas de abieiro. Belém: EMBRAPA; 2004. (Comunidade Técnico; no. 90).

Costa FG, Valeri SV, Cruz MCP, Gonzales JS. Esterco bovino para o desenvolvimento inicial de plantas provenientes de quatro matrizes de Corymbia citriodora. Scientia Forestalis 2011; 39(90): 161-169.

Da Ros CO, Rex FE, Ribeiro IR, Kafer OS, Rodrigues AC, Silva RF, et al. Uso de substrato compostado na produção de mudas de Eucalyptus dunnii e Cordia trichotoma. Floresta e Ambiente, 2015; 22(4): http://dx.doi.org/10.1590/21798087.115714

Dickson A, Leaf AL, Hosner JF. Quality appraisal of white spruce and white pine seedling stock in nurseries. Forestry Chronicle 1960; 36(1): 10-13. http://dx.doi.org/10.5558/ tfc36010-1.

Ferreira DA, Barroso DG, Silva MPS, Souza JS, Freitas TAS, Carneiro JGA. Influência da Posição das miniestacas na qualidade de mudas de cedro australiano e no seu desempenho inicial no pós-plantio. Ciência Florestal 2012; 22(4): 715-723. http://dx.doi.org/10.5902/198050987553. 
Fonseca EP. Padrão de qualidade de mudas de Trema micrantha (L.) Blume, Cedrela fissilis Veli. e Aspidosperma polyneuron Müll Arg. produzidas sob diferentes períodos de sombreamento [tese]. Jaboticabal: Universidade Estadual Paulista; 2000.

Frade EF Jr, Araújo JA, Silva SB, Moreira JGV, Souza LP. Substratos de resíduos orgânicos para produção de mudas de ingazeiro (Inga edulis mart) no vale do Juruá - Acre. Enciclopédia Biosfera 2011; 7(13): 959-969.

Gianello C, Ernani PR. Rendimento de matéria seca de milho e alterações na composição química do solo pela incorporação de quantidades crescentes de cama de frangos, em casa de vegetação. Revista Brasileira de Ciência do Solo 1983; 7(3): 285-290.

Giracca EMN, Nunes JLS. Tipos de fertilizantes. 2012 [cited 2015 Mar 3]. Available from: http://www.agrolink.com. br/fertilizantes/FormulacaodeAdubos.aspx

Gomes JM. Parâmetros morfológicos na avaliação da qualidade de mudas de Eucalyptus grandis, produzidas em diferentes tamanhos de tubete e de dosagens de N-P-K [tese]. Viçosa: Universidade Federal de Viçosa; 2001.

Jabur MA, Martins ABG. Influência de substratos na formação dos porta-enxertos: limoeiro-cravo (Citrus Limonia Osbeck) e tangerineira-cleópatra (Citrus Reshni Hort. ex Tanaka) em ambiente protegido. Revista Brasileira de Fruticultura 2002; 24(2): 14-518. http://dx.doi. org/10.1590/S0100-29452002000200047.

Luz JMQ, Morais TPS, Blank AF, Sodré ACB, Oliveira GS. Teor, rendimento e composição química do óleo essencial de manjericão sob doses de cama de frango. Horticultura Brasileira 2009; 27(3): 349-353. http://dx.doi.org/10.1590/ S0102-05362009000300016.

Miranda SC, Ribeiro RLD, Ricci MSF, Almeida DL. Avaliação de substratos Alternativos para produção de Mudas de Alface em Bandejas. Brasília: EMBRAPA; 1998. p. 1-6. (Comunicado Técnico; no. 24).

Moraes SP No, Gonçalves JLM, Arthur JRJC Jr, Ducatti F, Aguirre JH Jr. Fertilização de mudas de espécies arbóreas nativas e exóticas. Revista Árvore 2003; 27(2): 129-137. http://dx.doi.org/10.1590/S0100-67622003000200002.

Pereira PC, Melo B, Freitas RS, Tomaz MA, Freitas CJP. Mudas de tamarindeiro produzidas em diferentes níveis de matéria orgânica adicionada ao substrato. Revista Verde 2010; 5(3): 152-159.
Pinheiro AL, Lani JL, Couto L. Cedro Australiano: cultivo e utilização (Toona ciliata M. Roem. Var. australis (F. Muell) Bahadur). Viçosa: Universidade Federal de Viçosa; 2006.

Rondon RM No, Ramos CB. Avaliação das características físicas de substratos formulados com resíduos orgânicos para a produção de mudas florestais em tubetes. Pesquisa Aplicada \& Agrotecnologia 2010; 3(2): 117-122.

Rossa UB, Ângelo AC, Nogueira AC, Reissmann CB, Grossi F, Ramos MR. Fertilizante de liberação lenta no crescimento de mudas de Araucaria angustifolia e Ocotea odorifera. Floresta 2011; 41(3): 491-500. http://dx.doi. org/10.5380/rf.v41i3.24040.

Rossa UB, Ângelo AC, Nogueira AC, Westphalen DJ, Bassaco MVM, Milani JEF et al. Fertilizante de liberação lenta no desenvolvimento de mudas de Schinus terebinthifolius e Sebastiania commersoniana. Floresta 2013; 43(1): 93-104. http://dx.doi.org/10.5380/rf.v43i1.25690.

Sampaio PTB, Resende MDV, Araújo AJ. Estimativas de parâmetros genéticos e métodos de seleção para o melhoramento genético de Pinus caribaea var. hondurensis. Pesquisa Agropecuária Brasileira 2000; 35(11): 2243-2253. http://dx.doi.org/10.1590/S0100-204X2000001100017.

Santos JF, Grangeiro JIT, Olieira MEC. Produção da cultura da Mamoneira em função da fertilização com cama de galinha. Engenharia Ambiental 2010; 7(1): 169-180.

Silva AL, Morais GA. Influência de diferentes substratos no crescimento inicial de Ormosia arborea (Vell.) Harms (Fabaceae). Revista Verde 2013; 8(4): 22-27.

Sociedade Brasileira de Ciência do Solo - SBCS. Comissão de Química e Fertilidade do Solo - RS/SC. Manual de adubação e de calagem para os estados do Rio Grande do Sul e de Santa Catarina. 10. ed. Porto Alegre: Núcleo Regional Sul; 2004. 400 p.

Thomas R. Crescimento e nutrição de mudas de Pinus taeda L. no estado do Rio Grande do Sul [dissertação]. Santa Maria: Universidade Federal de Santa Maria; 2007.

Torres GN, Vendruscolo MC, Santi A, Soares M, Pereira PSX. Desenvolvimento de mudas de pinhão manso sob diferentes doses de cama de frango no substrato. Revista Verde 2011; 6(4): 244-250.

Wendling I, Dutra LF, Grossi F. Produção de mudas de espécies lenhosas. Colombo: Embrapa Florestas; 2006 (Embrapa Florestas. Documentos; no. 130). 